Łukasz RÓŻYCKI*

\title{
FEAR - AN ASPECT OF BYZANTINE PSYCHOLOGICAL WARFARE
}

The purpose of this piece is not to provide a comprehensive analysis of fear and how it affected the battlefields of antiquity - that would require at least a monograph, which is yet to be written ${ }^{1}$. The subject of study needs to be narrowed down, allowing us to concentrate on a single historical source and provide a concise analysis of the issue. Every scholar dealing with the past is aware that talking about the feelings of people in ancient times is difficult and oftentimes impossible ${ }^{2}$. By using analogies we may describe what it felt like for a legionnaire to face down the terrifying barbarian hordes with a sword in hand $^{3}$, surrounded by brothers-in-arms from his contubernium, but still these would be only speculations. It is difficult to account for all the cultural factors, just as it is hard to fully trust analogies. We can, however, by applying the concepts of social psychology, new military history and other fields of science, attempt to understand individual points of view and factors determining specific behaviors. Let's take, for example, melee combat - one of the most harrowing experiences that a soldier might be subjected to. He must stand face to face with the enemy, endure the mental and physical pressure and survive by killing his adversary. The feelings accompanying the act couldn't have changed much throughout the years, especially when we look at the course of numerous battles of late antiquity, which often ended with one side, whose morale

* Łukasz Różycki Ph.D., assistant professor of Byzantine History in the Historical Department of Adam Mickiewicz University in Poznań, permanent members of the International Interdisciplinary Archaeological Expedition Novae, e-mail: lukasz.rozycki@amu.edu.pl.

${ }^{1}$ However, the topic itself has already been researched to an extent. Polish studies in this regard are still in their infancy but there are notable English works, e.g. A.K. Goldsworthy, The Roman Army at War 100 BC-AD 200, Oxford 1996 (Polish translation: Armia rzymska na wojnie, transl. Ł. Różycki, Oświęcim 2013) or the analysis of classical Greek warfare e.g. D. Hanson, The Western Way of War: Infantry Battle in Classical Greece, New York 1987.

${ }^{2}$ See for example the interesting, although not flawless, attempts by J. Besala, Miłość $i$ strach. Dzieje uczuć kobiet i mężczyzn. Cywilizacje starożytne, Poznań 2010.

${ }^{3}$ Compare to contemporary military instructions on bayonet combat training: Ministerstwo Spraw Wojskowych, Instrukcja walki bagnetem (tymczasowa), Warszawa 1928; Ministerstwo Obrony Narodowej. Centralna Komisja Regulaminowa, Instrukcja walki bagnetem, Wielka Brytania 1943,5 . 
had been broken, fleeing in panic ${ }^{4}$. No matter the time period, a man finding himself in similar circumstances must have focused on a single thing - killing the enemy before the enemy does the same $e^{5}$. In the $20^{\text {th }}$ century, the author of a bayonet fighting manual wrote about melee combat: "The bayonet has been and will remain the last, but in mental terms the most effective weapon of an infantryman in close-quarters combat $[\ldots]$ a soldier is expected to rush into melee range and break the enemy's resistance with bayonet and martial skill"' .

Only written sources may give us a glimpse of the certain aspects of a soldier's life and identify some of the feelings of combatants. Unfortunately, Roman legionnaires did not write memoirs, and historians were more interested in major victories and their architects rather than the issue of fear on the battlefield. Despite all that, we may still attempt to look into the mind of a soldier of antiquity, but the process is complicated and risky ${ }^{7}$. A scholar wishing to at least partially understand fear on the field of battle must look for information beyond the monumental works of ancient historiography ${ }^{8}$. One group of sources that

${ }^{4}$ The psychological basis for these behaviors has been described in works commissioned by the Polish Armed Forces: S. Konieczny, Panika wojenna, Warszawa 1969; idem, Strach i odwaga w działaniach bojowych, Warszawa 1964.

${ }^{5}$ Learn about the basics of hand-to-hand combat in the US Army in: U.S. Army Hand-To-Hand Combat, New York 2012, 4-5.

${ }^{6}$ Instrukcja walki bagnetem, p. 5: “Ostatnim i pod względem psychicznym najsilniejszym argumentem piechura w walce na najbliższych odległościach jest i pozostanie - bagnet [...] żołnierz musi dążyć do starcia wręcz i złamania oporu przeciwnika bagnetem lub walką pierś o pierś”, transl. Ł. Różycki.

${ }^{7}$ On the topic of battlefield stress, but mostly the issue of post-traumatic stress disorder among Roman veterans see A. Melchior, Caesar in Vietnam: did Roman Soldiers Suffer from Post-Traumatic Stress Disorder?, "Greece \& Rome" 58 (2011) fasc. 2, 209-223. Not all attempts at applying a contemporary context and seeking analogies are successful. One of the worst examples is comparing heavy medieval cavalry to tanks and studying both weapon types as similar; studies of this sort were conducted, among others, by E.N. Luttwak (The Grand Strategy of the Byzantine Empire, Harvard 2009, 393-409).

${ }^{8}$ See the classic work C.A. du Picq, Etudes sur le combat, Paris 1868 or the study that is crucial for modern methodology of military history: J. Keegan, The Face of Battle, London 1976. One of the men who implemented Keegan's theses was A.K. Goldsworthy (see note 1). We also mustn't forget the work prepared for the U.S. Army by S.L.A. Marshall (Men against Fire, New York 1947) which was the first to highlight the importance of psychology in military operations. The first author to deal with the psychology of war was William James (The Moral Equivalent of War, in: The Works of William James - Essays in Religion and Morality, ed. F. Burkhardt, Cambridge 1982, 162-173) who in 1910 sought positive aspects of war in the context of the society. In the field of methodology it is worth mentioning the fundamental collection on the deconstruction of sources, which is the method commonly used by scholars following the trends of new military history (H. Bloom - P. de Man - J. Derrida - G.H. Hartman - J.H. Miller, Deconstruction \& Criticism, New York 1979). Among Polish scholars Ireneusz A. Łuć successfully introduced new methods to studies on social functions in the Roman army (see I. Łuć, Boni et Mali Milites Romani relacje między żolnierzami wojsk rzymskich $w$ okresie wczesnego cesarstwa, Kraków 2010). Also compare with more classic works, for example R. MacMullen, The Legion as a Society, "Historia" 22 (1984) fasc. 4, 440-456. 
can be used includes military treatises, which were often written by practitioners of warfare with field experience and a level of theoretical knowledge ${ }^{9}$. This particular article is based on Ars militaris $(\Sigma \tau \rho \alpha \tau \eta \gamma \imath \kappa o ́ v){ }^{10}$, a treatise created at the end of the $6^{\text {th }}$ century or in the first years of the $7^{\text {th }}$ century.

The author of Ars militaris was an experienced commander with ties to the court of Constantinople. It is possible that it was Philippicus ${ }^{11}$, the trusted $\sigma \tau \rho \alpha \tau \eta \gamma$ ó $\varsigma$ of Emperor Maurice, but we also cannot exclude the possibility that the emperor himself was actively involved in the creation of the work ${ }^{12}$. Regardless of the authorship, $\Sigma \tau \rho \alpha \tau \eta \gamma \iota \kappa o ́ v$ is certainly not an antiquarian piece, meaning that it was not written by a Byzantine humanities scholar dealing with something beyond his expertise ${ }^{13}$, but rather by a soldier addressing it to the other soldiers. This fact alone provides us with a completely new perspective and insight into aspects of warfare that are inaccessible otherwise.

Fear has accompanied humanity since the beginning of time. It motivates much of what we do but also stops us from acting too rashly ${ }^{14}$. Controlling one's anxieties has always been and remains to this day a source of great power $^{15}$. The impact of fear in the context of combat can be summed up in the words of one of Polish pioneers in its study, Józef Pieter: "In physiological terms fear means mobilizing the body's vital force and channeling it from within to be used for one's defense" ${ }^{\prime 16}$. Among different types of fear one of

${ }^{9}$ As noticed by W.E. Kaegi Jr. (Some Thoughts on Byzantine Military Strategy, in: Byzantine Warfare, ed. J. Haldon, Aldershot 2007, 260-261) the mixture of military literature with the experiences of past conflicts led to the emergence of a unique way of waging war in the Empire, which did not appear ex nihilo, but evolved from Greek and Roman treatises.

${ }_{10}$ Cf. Flavius Tiberius Mauricius, Ars militaris, in: Das Strategikon des Maurikios, ed. G.T. Dennis, transl. E. Gamillscheg, Wien 1981.

${ }^{11}$ A theory suggested by John Earl Wiita in an unpublished Ph.D. dissertation (J. Wiita, The Ethnika in Byzantine Military Treatises, University of Minesota 1977, 30-49). Also compare with the

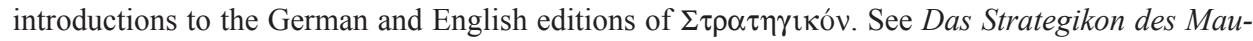
rikios, p. 15-18; Maurice's Strategikon: Handbook of Byzantine Military Strategy, transl. G.T. Dennis, Philadelphia 1984, XIV-XXI).

${ }^{12}$ Many scholars believe that emperor Maurice was actually the author of the treatise. Cf. F. Aussaresses, L'auteur de Stratégicon, REA 8 (1906) 23-40.

${ }^{13}$ Cf. G. Greatrex - H. Elton - R. Burgess, Urbicius' Epitedeuma: An edition, translation and commentary, ByZ 98 (2005) 38.

${ }^{14}$ See for example the following study: M. Zawadzki - M. Barska, Skamienieć ze strachu czy popchnać do działania? (Nad)używanie strachu w perswazji, in: Spotkania z psychologia społeczna, ed. B. Danieluk - K. Stasiuk, Lublin 2009, 34-46.

${ }^{15}$ Cf. D.L. Altheide, Creating Fear News and the Construction of Crisis, New York 2002, 14-18.

${ }^{16}$ J. Pieter, Strach i odwaga, Warszawa 1971, 45: "Fizjologicznie rzecz biorąc, strach oznacza najpierw mobilizację sił żywotnych organizmu, następnie zaś przerzucenie tych sił od wnętrza ku granicom organizmu dla jego obrony", transl. Ł. Różycki. For more, please see: A. Ohman, The Biology of Fear: Evolutionary, Neutral and Psychological Perspectives, in: Fear Across the Disciplines, ed. J. Plamper - B. Lazier, Pittsburgh 2012, 35-51. 
the strongest is the fear of losing life $^{17}$. This feeling is so intense that it often leaves a person completely paralyzed or overcome by the most basic instincts. The presence of fear on the battlefield is understandable and for any military man - it's actually natura ${ }^{18}$. The Romans turned mastering a soldier's fear into an art form, which to this day is employed with the same results ${ }^{19}$. Eliminating fear from the mentality of soldiers was achieved for example through military drills and an unforgiving training regime aimed at dulling the legionnaires' self-preservation instinct, which normally forces every man to for the first and foremost protect their own life ${ }^{20}$. The Roman army was the first one to unwittingly implement the idea of "balance of terror", which became widely recognized during the Cold $\mathrm{War}^{21}$. The functioning of Roman military was based on numerous factors, such as the carefully nurtured feeling of camaraderie, the fear of inevitable punishment for any infractions of discipline ${ }^{22}$, the fear of supervisors, the desire to ascend through the ranks ${ }^{23}$ and so on ${ }^{24}$. The

${ }^{17}$ It should be noted here that fear is an expression of one's experiences, which means that any person will react differently in a situation of danger. However, even if people overestimate certain threats and underestimate others, the feeling of fear is present in any life-threatening circumstances. See Pieter, Strach i odwaga, p. 54-57.

${ }^{18}$ The issue of fear and panic on contemporary battlefields was analyzed by Stanisław Konieczny (Panika wojenna; Strach i odwaga w działaniach bojowych). The topic was also partially covered in a more recent work: G. Nowacki, Organizacja i prowadzenie działań psychologicznych $w$ wybranych państwach, Torun 2004. An excellent overview of modern psychological warfare is presented in: MC 402/1 NATO Military Policy on Psychological Operations. On the subject of history of discipline, please refer to: C. Kennedy - E. Zillmer, Military Psychology Clinical and Operational Applications, New York 2006, 1-21.

${ }^{19}$ Psychological training in modern armies was studied by E. Hartmann - T. Sunde - W. Kristensen - M. Martinussen (Psychological Measures as Predictors of Military Training Performance, "Journal of Personality Assessment" 80 (2003) fasc. 1, 87-98). Please also see the fascinating piece by H. Halff - J. Hollan - E. Hutchins (Cognitive science and military training, "American Psychologist" 41 (1986) 1131-1139). It is notable that there are many similarities between the modern and ancient approach and that many methods of influencing the soldiers that are still in use had already been employed, albeit in simpler form, in the antiquity.

${ }^{20}$ Training in the Roman army was described by e.g. S.E. Phang, Roman Military Service: Ideologies of Discipline in the Late Republic and Early Principate, Cambridge 2008, 37-73. The subject was also touched upon in MacMullen, The Legion as a Society, p. 440-456.

${ }^{21}$ Cf. A. Wohlstetter, The Delicate Balance of Terror, "Foreign Affairs" 37 (1959) fasc. 2, 211 234; Pieter, Strach i odwaga, p. 98-100.

${ }^{22}$ On that subject see C. Brand, Roman Military Law, San Antonio 1968, and with regard to Strategikon: E.H. Freshfield, Roman Law in the Later Roman Empire Military Discipline of the Emperor Maurice c. A.D. 590 from the Strategikon, Cambridge 1947. Also, compare with this earlier work J. Bray, Essai Sur Le Droit Penal Militaire Des Romains: Droit International de L'Occupation Militaire en Temps de Guerre, Whitefish 2009. It is a reprint of Bray's dissertation, which itself is very hard to obtain, the first edition appeared in Paris in 1894.

${ }^{23}$ One of the aspects of boldness.

${ }^{24}$ Cf. Brand, Roman Military Law; Freshfield, Roman Law. For a look at the earlier period see also G. Kuleczka, Studia nad rzymskim wojskowym prawem karnym, Poznań 1974. Another author 
combination of all these components was supposed to shape men into soldiers who would be able to risk their lives and choose fight over flight in the face of the enemy. However, one question remains unanswered - did the generals of antiquity ${ }^{25}$ utilize terror on the battlefield as any other tool of war; were they able to harness its power, turning it into a valuable ally? And if so, was this intentional or only intuitive?

1. Strategikon in the context of military psychology. There are many aspects of Ars militaris that we might analyze in the context of social psychology or, narrowing down, battlefield psychology. Some stratagems had been known for centuries and the author simply copied them from other works. One good example is intentional misinformation in one's own ranks. In a large-scale battle commanders would sometimes tell the soldiers on one flank that the units on the other flank have already beaten the enemy, even if in reality the other flank was retreating at that moment. The goal was to urge the men on to greater efforts. A similar ruse was mentioned by Poliajnos ${ }^{26}$, who describes it as being used by Myronides. The Greek commander not only lifted up the spirits of his own men by spreading false information about the victory on the other flank, but also destroyed the enemy's morale, who supposedly heard the general's cries of victory. However, Ars militaris also deals with aspects, which in modern day vernacular would be referred to as psychological warfare, that do not appear in other works and require close examination. This article will focus on such unique ideas. First, let us look at the philosophy of warfare as practiced by the author of the treatise. This will give us a better understanding of the $6^{\text {th }}$ century approach to violence:

"War is like a hunt. Wildlife can only be bested by using reconnaissance, ensnaring, ambushing and other tricks instead of relying on brute force. While waging war we should act in a similar fashion, regardless of the number of adversaries. Attempting to face the enemy in open battle, even if victory is to be expected, may result in many casualties and is inherently risky. Barring a few special exceptions it is foolish to try and achieve victory and empty glory in such costly manner" 27 .

Likening war to hunting has a deeper meaning ${ }^{28}$. Both activities require much cleverness, focus and involvement. The above quote is also indicative of

who dealt with the topic of lawbreakers and punishments was M. Stachura (Wrogowie porzadku rzymskiego studium zjawiska agresji językowej w Kodeksie Teodozjusza, Nowelach Postteodozjańskich i Konstytucjach Sirmondiańskich, Kraków 2010, particularly pages 196-200).

${ }^{25}$ On contemporary ideas regarding leadership in the context of social psychology see

J. Borkowski, Podstawy psychologii społecznej, Warszawa 2003, 136-151.

${ }^{26}$ Cf. Polyaenus, Strategemata I 35; Sextus Iulius Frontinus, Strategemata II 4, 11.

${ }^{27}$ Mauricius, Ars militaris VIIA 1, 45-53, ed. Dennis, p. 230, transl. Ł. Różycki.

${ }^{28}$ Cf. A. Kotowska, Zwierzęta w kulturze literackiej Bizantyńczyków, Poznań 2013, 27-70. 
a Christian idea, which in the future would dominate Eastern Roman approach to war and violence, namely that the lives of soldiers are too precious to be put at risk for illusory benefits. A good commander must know when to give battle, which is always dependent on fortune ${ }^{29}$, and when to employ ruses that will help avoid unnecessary losses. Roman generals were trained to feel responsible not only for their country but also for the lives of their subordinates. In later years this doctrine was expanded and the $\sigma \tau \rho \alpha \tau \eta \gamma o$ ó were also expected to care for and safeguard the civilian population ${ }^{30}$. Summing up, a $6^{\text {th }}$ century Roman commander was equally responsible for his country as well as his men. As such, he should not commit his forces to battle if victory could be achieved by other means. It was the leader's duty to find a way that would ensure the enemy's defeat with little to no losses and without needless bloodshed. It may seem odd that a military commander was expected to avoid clashes with the foe, but we only need to look into the works of St Basil the Great to see that in the Eastern Christian tradition war was considered a misfortune and the profession of a soldier was not actually held in high regard ${ }^{31}$.

It is hard to imagine what a Roman soldier felt in the moments leading up to a fight. Fear for one's own life must have been paralyzing, and even being surrounded by brothers-in-arms was not always enough to soothe the nerves, especially facing an unknown enemy. In the $6^{\text {th }}$ century Romans were commonly forced to fight against adversaries that they've never encountered before. This often happened in the Balkans ${ }^{32}$, the dwelling place of not only Avars and Slavs but also a multitude of lesser tribes either fleeing from the nomads or aiding them ${ }^{33}$. In such cases pre-battle anxiety was intensified by rumors of an unknown enemy, often exaggerated. This could easily lead to mass hysteria, whose mechanisms are now well-known thanks to the study of conformity in collective action situations ${ }^{34}$. Roman generals did not have at their disposal any modern tools for analyzing the human psyche, but they were

${ }^{29}$ Cf. Mauricius, Ars militaris VIII 2, 4; VIII 2, 86.

${ }^{30} \mathrm{Cf}$. Niceforus Augustus, De velitatione bellica XII 4-15.

${ }^{31}$ Cf. M. Wojnowski, Religia a wojskowość bizantyńska w świetle traktatów wojskowych IX-XI wieku, "Przegląd Historyczny" 100 (2009) nr 2, 199-205. Basil the Great (Epistula 188) saw killing as one of the most grievous sins and believed that even soldiers who simply followed orders in this regard had to repent for taking the life of a fellow man.

${ }^{32}$ Cf. S. Turlej, Upadek granicy cesarstwa na Dunaju, in: Barbarzyńcy u bram Imperium, ed.

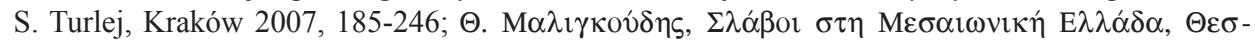
$\sigma \alpha \lambda$ ovıкп 1991; M. Whitby, The Emperor Maurice and his Historian Theophylact Simocatta on Persian and Balkan Warfare, Oxford 1988. An overview of Roman military in this period can be found in: I. Syvanne, The Age of Hippotoxotai Art of War in Roman Military Revival and Disaster (491-636), Tampere 2004.

${ }^{33}$ See an analysis of the topic in B. Zástěrová, Les Avares et les Slaves dans la Tactique de Maurice, Praha 1971.

${ }^{34}$ In the literature of the subject authors actually use a term "contagion of fear" when referring to a mob, in which individual awareness is dulled. Cf. Pieter, Strach i odwaga, p. 112-113; S. Baley, 
well aware of the danger of fear, which could lead to defeat before the battle even began. Because it could be a powerful factor, it was important to find ways to overcome it. The author of Ars militaris suggested simple methods:

"If we find ourselves waging war against a powerful adversary whose fighting methods are alien to our army, then our soldiers, not knowing what to expect, will become nervous. In such case one should be very careful and avoid open battle. Before the main clash the first and safest thing to do is to select a group of experienced and lightly equipped men and send them to attack the foe. If they successfully slay or capture several of the enemy soldiers then the whole army will see that we outmatch them. Doubts will disappear, morale will rise and the troops will learn how to fight this new adversary"35.

So the idea was to fight fire with fire. Modern psychology refers to such methods as taming fear or achieving bravery by accustoming to threatening situations $^{36}$. What the soldiers felt was anxiety caused by unknown threat, which disrupts the natural mental and physiological responses. In collective action situations this feeling was intensified by spreading false or exaggerated information about the enemy ${ }^{37}$. The basic mechanism of getting accustomed to fear can be explained in the following manner: "In order to get accustomed to danger men must first overcome their fears many times in a conscious way" 38 . Employing such methods shows the awareness of Roman generals. Not only were they aware of the problem, they also learned how to utilize the mechanism of spreading fear to combat it. The dread caused by facing an unknown adversary should be neutralized consciously and gradually, by familiarizing the whole army with the enemy. The $\sigma \tau \rho \alpha \tau \eta \gamma$ ós commanding the troops would choose veteran soldiers and send them off to harass the enemy using guerilla tactics. During such clashes the men quickly learned about the other side's fighting style, thus overcoming their fears. Each time a unit returned to camp after defeating the enemy ${ }^{39}$ rumors about it would spread like wildfire among the troops. So, the same mechanism of gossip, which usually resulted in lowering morale and arousing anxiety, was used to help the soldiers come to terms with the object of their fear. It remedied the phenomenon of thought

\footnotetext{
Wprowadzenie do psychologii spotecznej, Warszawa 1959, 106-114; C.A. Kiesler - S.B. Kiesler, Conformity, Boston 1969.

${ }^{35}$ Mauricius, Ars militaris VIIA 11, ed. Dennis, p. 238, transl. Ł. Różycki.

${ }^{36}$ Cf. Pieter, Strach i odwaga, p. 181-185.

${ }^{37} \mathrm{Cf}$. J. Dabbs - H. Leventhal, Effects of varying the recommendations in a fear-arousing communication, "Journal of Personality and Social Psychology" 4 (1966) 525-531.

${ }^{38}$ Pieter, Strach i odwaga, p. 182: "Aby się przyzwyczaić do odpierania niebezpieczeństwa, trzeba uprzednio wielokroć przełamywać strach świadomie”, transl. Ł. Różycki.

${ }^{39}$ Which is why it was crucial to choose only the best and most experienced soldiers for these missions, i.e. men who could guarantee success. Because if any of these detachments were defeated, the resulting impact on the morale of the rest of the army would be catastrophic.
} 
blocking, which normally paralyzes the stream of consciousness in individuals and whole groups ${ }^{40}$.

Even if only a few soldiers acquired actual experience in fighting the newly-encountered enemy, their success would impact the behavior of the army as a whole. It shows that Romans understood the mechanism of fear creation and had a wealth of practical knowledge in the field known today as the social psychology. There were also other ways of alleviating the anxiety of troops before the battle. One method was suggested by Vegetius, who urged commanders to stay within close distance to the enemy ${ }^{41}$. This would help the soldiers get accustomed to the sight of the opposing force and come to terms with the prospect of fighting. It was a direct method of taming fear. Although in the context of the whole army this approach was less effective than the one mentioned in Ars militaris, because the legionnaires had no direct contact with the foe. Nevertheless, the idea proposed by Vegetius also resulted in accustoming the men to the feeling of anxiety. As a side note, we should bear in mind that if a commander followed the advice of Ars militaris and his detached forces suffered a defeat it would be catastrophic for the army's morale. The method described by Vegetius, while more careful and conservative, did not carry any such risk.

Before confronting the enemy directly it was important to gain any possible advantage ${ }^{42}$. This included building up the morale of one's own soldiers and using simple ruses to trick the enemy. Both these approaches were exemplified perfectly by how the Romans treated their prisoners. First, let us see how captured members of the opposing force were used to encourage the troops and help them overcome their fear:

"If any foes should be captured by our patrols or if any deserters make their way to us, and they are well equipped and healthy, we should not let them be seen by our own men, but rather secretly send the prisoners away. However; if they look miserable, we need to make sure that the whole army gets a look at them; they should be stripped, paraded before our troops and forced to beg for their lives, so as to make our men believe that all the enemy's soldiers are the same"43.

\footnotetext{
${ }^{40}$ In a moment of terror the object of anxiety often becomes so powerful that it paralyzes and restricts the perception of affected individuals. Breaking through the thought blocks allows individuals to regain control and start reacting to danger consciously.

${ }^{41}$ Vegetius (Epitoma rei militaris III 10) also advised to engage smaller enemy forces, which were easier to defeat; it would allow the soldiers to get their first sight of blood and first taste of the hardships of war.

${ }^{42}$ Scaring the enemy with one's own superiority is a well-researched topic, although in contemporary times this is usually done in terms of authority rather than physical strength. Cf. Pieter, Strach i odwaga, p. 93-94.

${ }^{43}$ Mauricius, Ars militaris VIIA 5, ed. Dennis, p. 234, transl. Ł. Różycki.
} 
The fragment above perfectly illustrates the Roman approach to warfare and their ability to turn any situation to their advantage. Taking prisoners has always been a part of waging war ${ }^{44}$ and they have been used for various purposes throughout the years. The author of the treatise suggested that in certain situations they could serve to raise the spirits of one's forces. If the captives were poorly equipped, looked undernourished and were of small build, they were to be presented to the whole army. This public demonstration was combined with downright theatrical elements; the enemy soldiers, already in a pitiful state, were made to beg for mercy before the troops. After such a spectacle the Romans would surely gain a significant boost to their confidence. They must have felt that since all foes were supposed to be this weak, poorly equipped and cowardly, facing them in battle should not pose any threat. Fear of the enemy was replaced by contempt and self-assuredness. This process is otherwise known as inspiring courage through depreciation of values related to the object of anxiety ${ }^{45}$. This method of dealing with fear is only effective when it's based on causality ${ }^{46}$. This is exactly what's being described in Ars militaris the cause of anxiety was the enemy and as the enemy's strength was depreciated it alleviated fear and inspired courage among Roman soldiers.

The writers of antiquity were well aware that this was a double-edged sword and that if any Roman soldiers were captured they could be used in the same manner. That is why troops sent out on reconnaissance missions were selected to strict standards:

"Patrol troops need to be reliable, well-built, and better equipped than the rest of the army. If they engage the enemy they will make an imposing impression and if they are captured the foe will be impressed by their physique and weaponry"47.

This stratagem is based on reversing the mechanisms that cause anxiety. Since recon troops will be the first to come into contact with the enemy, they needed to be soldiers of exceptional quality. The goal was to arouse fear in the opposing force. In the event of a confrontation, if a Roman patrol came out victorious, it would lead to rumors among the enemy's ranks about the quality of Roman troopers; and if the patrol was captured, it only served to give credence

${ }^{44}$ See for example R.C. Doyle, The Enemy in Our Hands: America's Treatment of Enemy Prisoners of War from the Revolution to the War on Terror, Washington 2010; R. Ambüh, Prisoners of War in the Hundred Years War: Ransom Culture in the Late Middle Ages, Cambridge 2013; A. Krammer, Prisoners of War: A Reference Handbook, Washington 2008.

${ }^{45}$ J. Pieter (Strach i odwaga, p. 187) describes similar methods for overcoming anxiety; in his studies it is not the object of fear that is depreciated but rather the cause. For example, soldiers fight better if they reject, at least partially, the concern for their own life. So, the value of a soldier's life is depreciated.

${ }^{46} \mathrm{Cf}$. ibidem.

${ }^{47}$ Mauricius, Ars militaris IX 5, ed. Dennis, p. 326, transl. Ł. Różycki. 
to these rumors. This was why reconnaissance units had to have high morale ${ }^{48}$, good physical attributes and better equipment than the rest of the force. If the enemy troops caught a glimpse of such imposing prisoners ${ }^{49}$, they likely began to wonder if all Romans were like that. It was a simple method to inspire fear among the enemy troops, even if it was the Romans who were captured. The key issue was choosing suitable men for the job. A similar trick, to be used on enemy prisoners, was suggested by the author of Tactica ${ }^{50}$. The Byzantine commander was expected to choose the most powerful-looking soldiers, equip them with the best weaponry and present them to the captives. The prisoners were then released, convinced about the might of the Byzantine army, often carrying falsified information about planned movements of the Romans ${ }^{51}$.

2. The rhetoric of combat. Just before the battle itself the tension among the rank and file troops must have been unbearable. Contrary to the opinion of Mogens Herman Hansen ${ }^{52}$ speeches preceding the clash did take place, although differing slightly from what has been preserved in the works of great historiographers. The author of Ars militaris was a practitioner of warfare, so he knew not to refer to any higher values when addressing the soldiers. This is what the treatise suggests:

"Find an opportune moment to gather the troops by meros or moira, not all at once in one place. Address the soldiers with suitable words, encourage them, bring to mind previous victories, promise rewards from the Emperor and payment for their service to the state. Next, archons should read out written orders to their tagma"s3.

The author of Ars militaris considered such addresses to be an important component of leading others ${ }^{54}$ and believed that a good leader should know the principles of rhetoric and make use of them when dealing with his subordinates $^{55}$. Highlighting the role of speeches in Ars militaris and emphasizing the significance of oratory skills indicate that in the times of Maurice the $\sigma \tau \rho \alpha \tau \eta-$ yoi did in fact address the troops before battles. Using the suggestions found in the treatise allowed the generals to overcome the technical difficulties of

\footnotetext{
${ }^{48}$ Cf. ibidem IX 5, 51-58.

${ }^{49}$ The author of Ars militaris suggested that strong-looking prisoners be secretly led away to the back lines. Cf. Mauricius, Ars militaris VIII 2, 29.

${ }^{50}$ Cf. Leo Sapiens, Tactica XVII 91.

${ }^{51}$ Cf. Mauricius, Ars militaris VIII 2, 29.

${ }^{52}$ Cf. H.M. Hansen, The Battle Exhortation in Ancient Historiography. Fact or Fiction?, „Historia" 42 (1993) fasc. 2, 161-180.

${ }^{53}$ Mauricius, Ars militaris VIIA 4, ed. Dennis, p. 232-234, transl. Ł. Różycki.

${ }^{54}$ Cf. Onasandros, Strategikos I 13-17; XIV.

${ }^{55} \mathrm{Cf}$. Mauricius, Ars militaris VIII 2, 93; VIII 2, 101.
} 
the antiquity ${ }^{56}$ - when officers addressed single units they were heard loud and clear by every soldier. The author of Ars militaris explains that speeches should not be given on the battlefield, but rather before the fighting started, in the camp ${ }^{57}$. In the moments leading up to the battle itself the soldiers had to be focused and maintain complete silence ${ }^{58}$. Also, it is notable how Romans approached the issue of morale - the fear of the enemy was supposed to be replaced by the desire to win rewards from the commander. Proper motivation was required to overcome anxiety ${ }^{59}$ and inspire courage. The leader would also recount previous Roman victories in order to depreciate the enemy. The goal was to make the soldiers think that since they've beaten this foe before, they will surely do it again.

Worth mentioning here is the work of Vegetius. It confirms that the approach described above was standard procedure for Roman commanders, which already in the $6^{\text {th }}$ century has been followed for hundreds of years. Vegetius suggested inspiring hatred towards the opposing force ${ }^{60}$ as the most effective method of motivating the army ${ }^{61}$. Both authors talked about downplaying the achievements of the enemy and emphasizing Roman victories, thus

${ }^{56}$ Julius Caesar (Commentarii de bello civili III 90) used a different method to make sure that all the soldiers heard the leader's address. It is also worth mentioning the speech given by Julian the Apostate to his men before the battle of Strasburg. The army was drawn up around the commander in columns, which made it possible for most of the soldiers to hear the leader's words (cf. Ammianus Marcellinus, Rerum gestarum libri XII 7).

${ }^{57}$ A speech given on the day preceding the battle did not have to be elaborate or follow the principles of rhetoric. It was addressed to simple soldiers, and the speaker's goal was to encourage them and suppress their fears. It could have easily been as brief as the one given by Julius Caesar, which was only 50 words (Hansen, The Battle Exhortation in Ancient Historiography, p. 171).

${ }^{58} \mathrm{Cf}$. Mauricius, Ars militaris II 18. Maintaining absolute silence was also an element of psychological warfare. This stratagem was used by the Roman forces in battle against Baram. The significance of this approach is apparent seeing as how $\sigma \tau \rho \alpha \tau \eta \gamma$ ó Narses asked the allied commander to order his men to do the same (cf. Theophylactus Simocatta, Historia V 9, 5-7). However, in the collection of maxims we find a statement expressing a completely opposite attitude: An army whose war cries are loud and clear may terrify the enemy (cf. Mauricius, Ars militaris VIIIB 46). The chapter of the treatise containing these adages is more antiquarian in character, but we cannot reject it outright and conclude that Romans in that period made no sound during battle. It's possible that there were exceptions from the rule. One explanation that reconciles these inconsistencies can be found in the work of Vegetius. He claimed that soldiers were allowed to raise war cries (barritus), but exclusively in hand-to-hand combat. In the opinion of Vegetius (Epitoma rei militaris III 18), only barbarians and cowards would shout from a distance.

${ }^{59} \mathrm{Cf}$. H. Leventhal - J. Watts - C.F. Pagano, Effects of fear and instructions on how to cope with danger, "Journal of Personality and Social Psychology" 6 (1967) fasc. 3, 313-321.

${ }^{60}$ Courage achieved through anger can give soldiers a significant edge. In terms of polarity, courage is fear transformed into anger. Cf. Pieter, Strach $i$ odwaga, p. 185.

${ }^{61} \mathrm{Cf}$. Vegetius, Epitoma rei militaris III 12. The work of Vegetius does not mention any prebattle addresses, but the author does specify what a good leader should say to his subordinates on the day of the engagement. The most convenient approach, especially in the case of a large army, 
breeding contempt for the foe. Also, the stories didn't have to be true; generals would sometimes spread false information in order to raise morale. This advice is repeated in Ars militaris:

"A leader should strengthen the morale/courage of his soldiers with rumors about the army's successes on other fronts" $"$.

J. Pieter stated that in the case of courage inspired through fear and anger a natural byproduct will be recklessness, self-confidence and belligerence. These attitudes will also be accompanied by slander, defamation, underestimation, sarcasm and irony ${ }^{63}$. Granted, Pieter's study does not deal with such extreme situations as hand-to-hand combat and refers rather to individuals, but we can easily extrapolate the results to group behaviors. So when the author of Ars militaris wrote about manipulating the minds of soldiers, he was actually describing the mechanism of inspiring courage through anger, which admittedly produced the best results on the battlefield ${ }^{64}$. It was even acceptable to use lies.

3. The day of battle. The battle itself was often treated as merely a game of chance ${ }^{65}$, in which the commanding officer was only a single component of a larger whole, with no apparent impact on the outcome ${ }^{66}$. The role of the general became more prominent once the fighting was done; the decisions made at the top of the command chain were often of crucial importance to the future of common soldiers and the army as a whole. If a battle had been undecided and was to be continued on the following day, the author of Ars militaris suggested a straightforward method of lowering the enemy's morale:

"Our own fallen should be buried together, secretly, at night, while the enemy dead are to be left on the field so that their comrades lose their nerve" ${ }^{" 67}$.

This is using terror in the contemporary sense of the word. To terrorize means to purposefully incite a feeling of intense dread, which paralyzes the individual; this is often accompanied by fear for one's life ${ }^{68}$. Bodies scattered on the ground were supposed to do just that - paralyze the adversary with fear ${ }^{69}$. The

would be to give a speech personally or write it down and distribute among the officers, who would then read it out loud to their units.

${ }^{62}$ Mauricius, Ars militaris VIII 1. 8, ed. Dennis, p. 270, transl. Ł. Różycki.

${ }^{63}$ Cf. Pieter, Strach i odwaga, p. 185.

${ }^{64}$ Battle readiness, aggression.

${ }^{65} \mathrm{Cf}$. Mauricius, Ars militaris VIII 2, 4.

${ }^{66}$ During the battle a commander could only observe how his plans played out and, if necessary, make use of any troops left in reserve. Cf. Mauricius, Ars militaris VIIB 1.

${ }^{67}$ Mauricius, Ars militaris VIII 1, 16, ed. Dennis, p. 272, transl. Ł. Różycki. I would like to thank Prof. P. Kochanek for valuable input regarding interpretation of Greek text.

${ }^{68}$ Cf. Pieter, Strach i odwaga, p. 100-103.

${ }^{69}$ We should also consider the religious ramifications. Cf. Polyaenus, Strategemata I 28. 
sight of dead brothers-in-arms, who fought in the same clash, caused anxiety in those who survived. However, as was already mentioned, a good commander could turn this anxiety into anger, a decisive advantage in any confrontation ${ }^{70}$. As such, this stratagem was effective, but it was possible for it to backfire.

Pre-battle stress could make the soldiers turn and flee even before the engagement began ${ }^{71}$, but it was actually the period following a defeat that was the most destructive to any army's morale. Such circumstances made it difficult to lift the spirits of the troops and the fact that dead comrades and victorious enemy forces were nearby could well lead to mass panic. The author of Ars militaris understood that this would in turn result in the destruction of the whole army, even when the defeat was not overwhelming. Provided that soldiers were still disciplined and it was still possible to achieve victory, Ars militaris provides some suggestions on how to suppress their anxiety:

"Troops defeated in open battle should not be given a break, even though it may seem a good idea. They should not be led to the safety of fortifications but rather attack once more, while their fear is still fresh. As long as the commander doesn't allow for loosening of discipline, the men will get back into the fight with more self-confidence" $"$.

This is a bold statement, most probably stemming from the author's experience in the field. Defeat results in depression, which may easily turn into apathy ${ }^{73}$, making people unresponsive. Although there are no clinical studies regarding the soldiers' reactions to failure in life-threatening situations, we may assume that the troops would be discouraged and fraught with despair. It is difficult to find a way to overcome these feelings. In Ars militaris the author advises against retreating to safety ${ }^{74}$ or showing leniency to soldiers, as this could intensify the feeling of anxiety and inhibit any action. Instead, the leader was supposed to immediately encourage the men and lead them to another attack, but only if their morale was not completely broken ${ }^{75}$. The idea was to get back in the saddle before the trauma of defeat becomes permanent, while the troops are still able to face the enemy and their fears. Aiming for this breakthrough was risky, but doing nothing could have even worse consequences ${ }^{76}$. Working out the strategy described above required detailed knowledge about the human

\footnotetext{
${ }^{70}$ Cf. Pieter, Strach i odwaga, p. 101-102.

${ }^{71}$ Panic and contagion of fear have already been described in brief.

${ }^{72}$ Mauricius, Ars militaris VIII 1, 43, ed. Dennis, p. 276-278, transl. Ł. Różycki.

${ }^{73}$ A state of highly diminished sensitivity to physical stimuli. For more information, see B. Miedzińska, Podstawy psychologii, Jelenia Góra 2010, 66.

${ }^{74}$ On the subject of safe locations and fear of them, see J. Mieszkowski, Fear of a Safe Place, in: Fear Across the Disciplines, p. 35-51.

${ }^{75}$ Cf. Mauricius, Ars militaris, VIIB 11, 18-23.

${ }^{76}$ Cf. D. Doliński - R. Nawart, Fear-then-relief procedure for producing compliance: Beware when the danger is over, "Journal of Experimental Social Psychology" 34 (1998) fasc. 1, 27-51.
} 
psyche. This knowledge must have come from the author's experience or from past military theorists whose works influenced Ars militaris.

On the other hand, in book VII of the treatise dealing with the issue of defeat, we find the following passage, showing a deep understanding of human mind:

"If the enemy is victorious in the first day of the engagement, we believe that it is entirely pointless and ill-advised to try and make the same forces defeated on the field attack once more on the next day or in the near future. We urge every strategos to not even consider this course of action. Any soldier would find that order hard to follow. It is not the custom of any people to rush back into battle after being defeated, with the exception of the Scythians, and to the Romans this attitude is completely alien. Even if the strategos is aware of the mistakes he made and hopes to redeem himself in the second battle, his soldiers will not understand the reasons for sending them against the enemy once more. They will rather see the outcome of the first engagement as a sign of divine will and lose all their fervor $[\ldots]^{\prime \prime 77}$.

An army could continue fighting only as long as its spirit was not broken ${ }^{78}$. If the mental condition of the soldiers suggested that they were unfit for battle, battle should be avoided. Otherwise it could result in disaster, even if the commander understood why his plan failed the first time and could prevent himself from making the same mistakes, because any army without the will to fight would be completely routed by the enemy. In this case psychology was the deciding factor.

$* * *$

The aforementioned examples of stratagems suggested on the pages of Ars militaris designed to affect the minds of the troops are only a small part of a larger whole. Comprehensive studies of Roman and Byzantine army in the context of psychology are still in their initial stages, but it is already evident that there is potential for future research in the field. This article merely touches upon a single issue of fear based on one military treatise. The conclusions encourage further studies. Roman generals were well aware of the power of fear and knew how to use it. One of the keys to success on the battlefield was overcoming the anxiety of one's own troops, while inspiring terror in the enemy provided another significant advantage. Despite not knowing the specific mechanisms governing the human mind, which have only recently

${ }^{77}$ Mauricius, Ars militaris VIIB 11, 1-15, ed. Dennis, p. 250, transl. Ł. Różycki.

${ }^{78}$ And even then the author of the treatise suggested regrouping and making sure that reserve forces, which did not take part in the defeat, be deployed at the forefront. Cf. Mauricius, Ars militaris VIIB 11, 18-23. 
been studied by modern science, Roman commanders intuitively made use of them. Their skill stemmed from centuries of observations of social behaviors in the specific environment of the army. However, even a small glimpse into the mind of the Roman soldier brings us this much closer to understanding the men of antiquity. This is possible by employing modern research methods, which provide historians, archeologists and classical philologists with tools they've never dreamed of ${ }^{79}$.

\section{STRACH - ELEMENT BIZANTYŃSKIEJ WOJNY PSYCHOLOGICZNEJ}

\section{(Streszczenie)}

Celem artykułu jest ukazanie, w jaki sposób strach oddziaływał na starożytnych żołnierzy. W badaniach wykorzystano metody stosowane w nowej historii wojskowości oraz elementy warsztatu psychologii społecznej, zwłaszcza jej części traktującej o zachowaniach zbiorowych. W celu dokonania analizy, autor wykorzystał traktat wojskowy z końca VI w. - Ars militaris $(\Sigma \tau \rho \alpha \tau \eta \gamma \imath \kappa o ́ v)$ oraz inne teksty źródłowe, pełniące funkcję pomocniczą. Dzięki zastosowaniu źródła spisanego przez autora będącego praktykiem, udało się uchwycić elementy późnorzymskiej sztuki wojennej, które dziś określamy mianem wojny psychologicznej. Autor artykułu postawił hipotezę, że starożytni dowódcy świadomie wykorzystywali strach jako pożyteczne narzędzie motywujące własnych żołnierzy oraz demotywujące wojska przeciwnika; w zakończeniu podkreślił jednak, że dalsze badania nad tym zagadnieniem są konieczne, a wyniki należy interpretować bardzo ostrożnie w przypadku stosowania nowoczesnego kotekstu.

Key words: Roman army, military psychology, fear, ars militaris.

Słowa kluczowe: armia rzymska, psychologia pola walki, strach, ars militaris.

${ }^{79}$ As was already mentioned in the introduction, such studies bear the risk of errors and inappropriate application of modern context. It should be noted that caution is required when analyzing any results in the context of contemporary social psychology. 
